\title{
The Absorption and Metabolism of Heavy Metals and Mineral Matters in the Halophyte Plant Artemisia aucheri
}

\author{
Abed Vahedi ${ }^{1}$ \\ ${ }^{1}$ Department of Agronomy and Plant Breeding, Qaemshahr Branch, Islamic Azad University, Qaemshahr, Iran \\ Correspondence: Abed Vahedi, Department of Agronomy and Plant Breeding, Qaemshahr Branch, Islamic Azad \\ University, Qaemshahr, Iran. E-mail: abedvahedy@gmail.com
}

Received: May 13, 2011 Accepted: June 9, 2011 Online Published: December 24, 2012

doi:10.5539/ijb.v5n1p63 URL: http://dx.doi.org/10.5539/ijb.v5n1p63

\begin{abstract}
To our knowledge there has been no research on Artemisia aucheri as a halophyte plant, when grown in cadmium $(\mathrm{Cd})$ contaminated soils. We tried to quantify the ability of A. aucheri in uptake of Cd and some nutrients in contaminated soil. In a pot culture experiment, five levels of $\mathrm{Cd}$ concentration were tested by adding 15, 30, 60, 120 and $240 \mathrm{mg}$ of Cd per kilogram of dried soil. Plants were harvested and analyzed for Cd, N, P, K, $\mathrm{Mg}, \mathrm{Mn}, \mathrm{Cu}, \mathrm{Fe}$ and $\mathrm{Zn}$ uptake. Depression in biomass production of plants as a result of excess $\mathrm{Cd}$ was observed. Cadmium concentration in plant shoots plant increased with increasing Cd supply significantly affecting the content of plant nutrients. Cd excess amounts increased macronutrients and decreased micronutrients concentrations in plant.
\end{abstract}

Keywords: Artemisia aucheri, biomass roduction, cadmium, nutrients

\section{Introduction}

Heavy metal contamination of soil and groundwater causes major environmental and human health problems. The commonly used methods for extraction of heavy metal from the environment are expensive (Singh et al., 2006). Phytoremediation is one of the effective technologies for this goal. Hence, in this technology testing and introducing new plants are very important. In addition salinity is also common in different parts of the world. Therefore, investigating the survival of salt-tolerant halophytes under heavy metal stress seems pertinent (Shevyakova et al., 2003).

Cadmium is one of the most important environmental contaminants with limited solubility in soils and hence limited availability for plant uptake (McBride, 1994). There has been extensive research regarding the accumulation of heavy metals in different plant species that has made the industry develop phytoextraction strategies to remediate heavy metal contaminated areas (Glass, 2000).

When plants are subjected to the excess amounts of $\mathrm{Cd}$ genetical, biochemical and physiological changes are resulted, eventually, leading to plant phyto-toxicity, and hence plant decreased growth (Liao et al., 2005; Nouairi et al., 2006; Siroka et al., 2004). There are interaction effects between heavy metals and essential macro and micronutrients, considerably affecting plant nutrient uptake (Pal et al., 2006).

The plant we chose for our approach is Artemisia aucheri from Poaceae family. It is a halophyte plant that grows in saline soils of Iran. To our knowledge, no studies have been reported with $A$. aucheri plants. The aim of our research was to investigate the effects of excess cadmium on biomass production, Cd concentration, and uptake and translocation of some nutrients including nitrogen $(\mathrm{N})$, phosphorus $(\mathrm{P})$, potassium $(\mathrm{K})$, magnesium $(\mathrm{Mg})$, iron (Fe), manganese (Mn), copper (Cu) and zinc ( $\mathrm{Zn})$ in A. littoralis.

\section{Materials and Methods}

This study was conducted under glasshouse conditions. The soil was collected from the top $20 \mathrm{~cm}$ layer from the arable plots. The soil was air dried and sieved to $<2 \mathrm{~mm}$ before use and characterized to determine different soil properties including organic carbon (OC, 0.076\%), Total $\mathrm{N}(0.084 \%), \mathrm{P}_{\text {avail }}\left(17 \mathrm{mg} \mathrm{kg}^{-1}\right), \mathrm{K}_{\text {avail }}\left(213.75 \mathrm{mg} \mathrm{kg}^{-1}\right)$, $\mathrm{Fe}_{\text {avail }}\left(5.54 \mathrm{mg} \mathrm{kg}^{-1}\right), \mathrm{Cu}_{\text {avail }}\left(47.8 \mathrm{mg} \mathrm{kg}^{-1}\right), \mathrm{Zn}_{\text {avail }}\left(490 \mathrm{mg} \mathrm{kg}^{-1}\right), \mathrm{Mg}_{\text {avail }}\left(1992.5 \mathrm{mg} \mathrm{kg}^{-1}\right), \mathrm{Mn}_{\text {avail }}(162.5 \mathrm{mg} \mathrm{kg}$ $\left.{ }^{1}\right), \mathrm{Cd}\left(0.25 \mathrm{mg} \mathrm{kg}^{-1}\right.$ soil dry weight). Ten $\mathrm{Kg}$ of soil was placed into pots. The soil was contaminated using five levels of $\mathrm{Cd}\left(\right.$ as $\left.\mathrm{CdCl}_{2}\right): 15,30,60,120,240 \mathrm{mg} \mathrm{kg}^{-1}$ plus a control. Three transplants of two-week old $A$. aucheriwere transplanted into each pot. $A$. aucheriis a permanent plant that regrowing from underground parts. 
Plant samples were taken at three different stages including 80, 160 and 240 days after planting. After the third harvest, roots were extracted from pots and washed with tap and distilled water.

\subsection{Cd and nutrients Analysis}

Plant materials of each stage were analyzed for Cd concentration. Plant samples were divided into stems and leaves and washed thoroughly with distilled water. Samples were oven dried at $70{ }^{\circ} \mathrm{C}$ for $24 \mathrm{~h}$. The dried plant material was ground and digested with a mixture of concentrated $\mathrm{HNO}_{3}$ and $\mathrm{HClO}_{4}$. Analysis of $\mathrm{Cd}$ in the stems and leaves was performed by Atomic Absorption Spectrophotometer.

At the third stage, all three stages shoot samples from all three samplings were combined and concentrations of nutrients $(\mathrm{N}, \mathrm{P}, \mathrm{K}, \mathrm{Cu}, \mathrm{Fe}, \mathrm{Cu}, \mathrm{Mn}, \mathrm{Mg}$ and $\mathrm{Zn}$ ) were determined. Total $\mathrm{N}$ and total $\mathrm{P}$ were measured by Berthelot reaction and molybdenum blue method, respectively (Page et al., 1982). Other nutrients were measured by Atomic Absorption Spectrophotometer.

\subsection{Statistical Analysis}

Analysis of variance (ANOVA) was performed at a level of $95 \%$ confidence using SAS software. Means were compared using least significant difference (LSD protected) method at $P=0.05$.

\section{Results}

\subsection{Dry Matter Production}

Increasing concentration of $\mathrm{Cd}$ significantly decreased leaf and stem dry matter production of plants $(p<0.05)$ (Figure 1 and Figure 2).

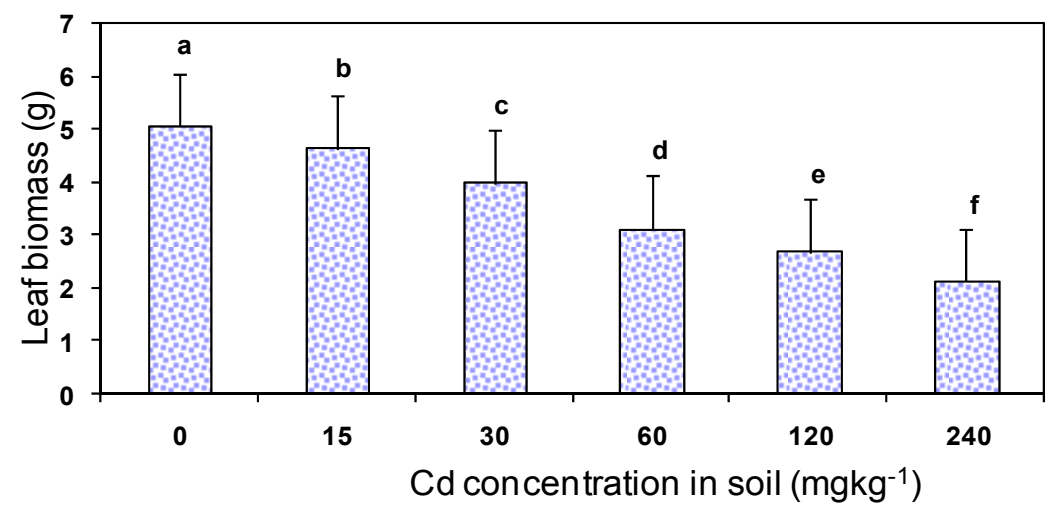

Figure 1. Leaf dry mater of Artemisia aucheriafter exposure to various $\mathrm{Cd}$ concentrations. Mean values within the same column, followed by different letters are significantly different using LSD protected test $(p<0.05)$.

Data represent means \pm S.D.

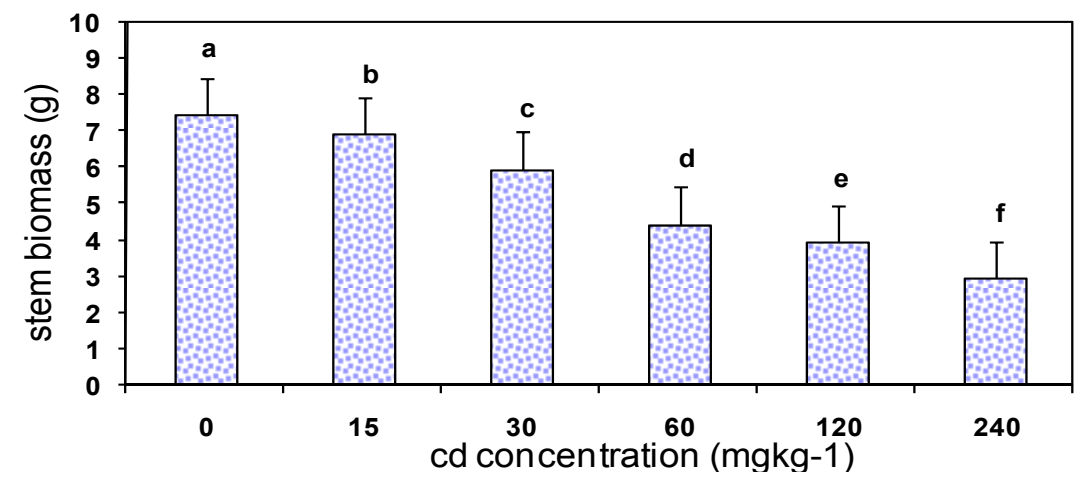

Figure 2. Stem dry mater of Artemisia aucheriafter treating with various $\mathrm{Cd}$ concentrations. Mean values within the same column, followed by different letters are significantly different using LSD protected test $(p<0.05)$.

Data represent means \pm S.D. 


\subsection{Plant Cd Accumulation}

Cadmium accumulation in shoots increased markedly with increasing $\mathrm{Cd}$ concentrations in soil. The highest concentration of $\mathrm{Cd}$ was $77.05 \mathrm{mg} \mathrm{kg}^{-1}$ dry weight $(p<0.05)$ (Figure 3). Cadmium concentrations in roots significantly increased with Cd levels increasing from 15 to $60 \mathrm{mg} \mathrm{kg}^{-1}$, and then significantly decreased as $\mathrm{Cd}$ concentrations increased from 60 to $240 \mathrm{mg} \mathrm{kg}^{-1}$. Cd concentrations in shoots were higher than those in roots $(p$ $<0.05$ ) (Figure 3).

\section{$3.3 \mathrm{~N}$ Content of Leaf, Stem and Root}

The applied concentrations of Cd significantly influenced the $\mathrm{N}$ content of leaf, stem and root (data not presented). In leaves, the concentration of $\mathrm{N}$ increased with an increase in Cd supply up to $120 \mathrm{mg} \mathrm{kg}^{-1}(p<$ $0.05)$, then decreased significantly as Cd concentration increased to $240 \mathrm{mg} \mathrm{kg}^{-1}$ dry soil $(p<0.05)$ (Figure 4$)$.

The stem $\mathrm{N}$ concentration significantly increased with increasing Cd content $(p<0.05)$ (Figure 4). Nitrogen concentrations in the A. aucheri leaves and roots grown in the control and $240 \mathrm{mg} \mathrm{kg}^{-1}$ treatment were significantly lower than the other treatments $(p<0.05)$ (Figure 4$)$.

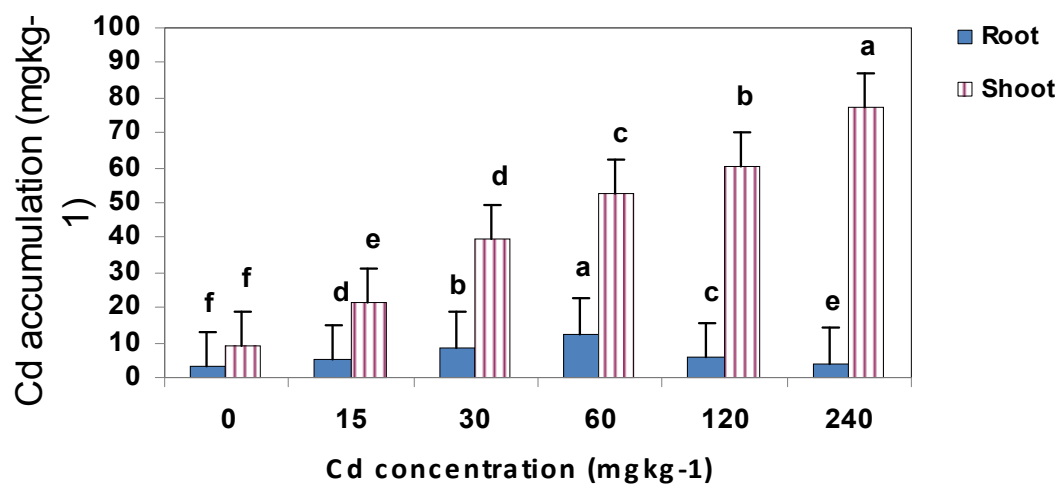

Figure 3. The concentration of $\mathrm{Cd}$ in shoots and roots of Artemisia aucheriafter treating with various $\mathrm{Cd}$ concentration. Mean values within the same column, followed by different letters are significantly different using LSD protected test $(p<0.05)$. Data represent means \pm S.D.

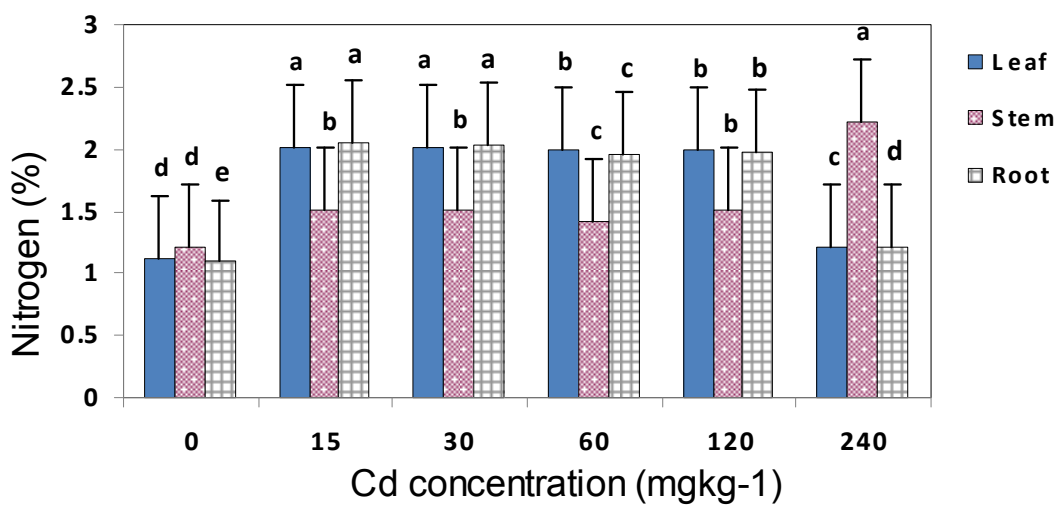

Figure 4. The concentration of $\mathrm{N}$ in leaves, stems and roots of Artemisia aucheriafter treating with various $\mathrm{Cd}$ concentration. Mean values within the same column, followed by different letters are significantly different using LSD protected test $(P<0.05)$. Data represent means \pm S.D.

\subsection{P Content of Leaf, Stem and Root}

Figure 5 shows the concentration of $\mathrm{P}$ measured in A. aucheri plant tissues. Relative to the other treatments, $\mathrm{P}$ content in leaves, stems and roots was significantly higher when Cd concentration ranged from $15-30 \mathrm{mg} \mathrm{kg}^{-1} . \mathrm{P}$ content of leaf, stem and root decreased significantly when Cd concentration increased from 30 to $120 \mathrm{mg} \mathrm{kg}^{-1}$ 
dry weight soil. The $\mathrm{P}$ content of plant tissues increased again for the $240 \mathrm{mg} \mathrm{kg}^{-1}$ treatment $(p<0.05)$ (Figure $5)$.

\subsection{K Content of Leaf, Stem and Root}

$\mathrm{K}$ content of plant tissues were significantly affected by different $\mathrm{Cd}$ concentrations in soil $(p<0.05)$ (Figure 6 ). As seen in Figure 6, K concentration in leaves and roots treated by different $\mathrm{Cd}$ concentrations followed the same pattern. It was maximal at the concentration of $15 \mathrm{mg} \mathrm{kg}^{-1}$. However, when Cd concentration increased to $120 \mathrm{mg} \mathrm{kg}^{-1}$, the $\mathrm{K}$ accumulation in A. aucheri leaves and roots reduced from 1661.38 to 1523.4 and from 1656.6 to $1519.62 \mathrm{mg} \mathrm{kg}^{-1}$ dry weight, respectively. Also, an increase in $\mathrm{K}$ concentration in leaves and roots was observed in the concentration of $120 \mathrm{mg} \mathrm{kg}^{-1}$ to $240 \mathrm{mg} \mathrm{kg}^{-1}(p<0.05)$ (Figure 6).

The results showed that plants grown in uncontaminated soil had the highest content of $\mathrm{K}$ in stems $(p<0.05)$. A decrease in stem $\mathrm{K}$ was observed when $\mathrm{Cd}$ concentration increased from 15 to $120 \mathrm{mg} \mathrm{kg}^{-1}$, then it increased at $240 \mathrm{mg} \mathrm{Cd} \mathrm{kg}{ }^{-1}(p<0.05)$ (Figure 6).

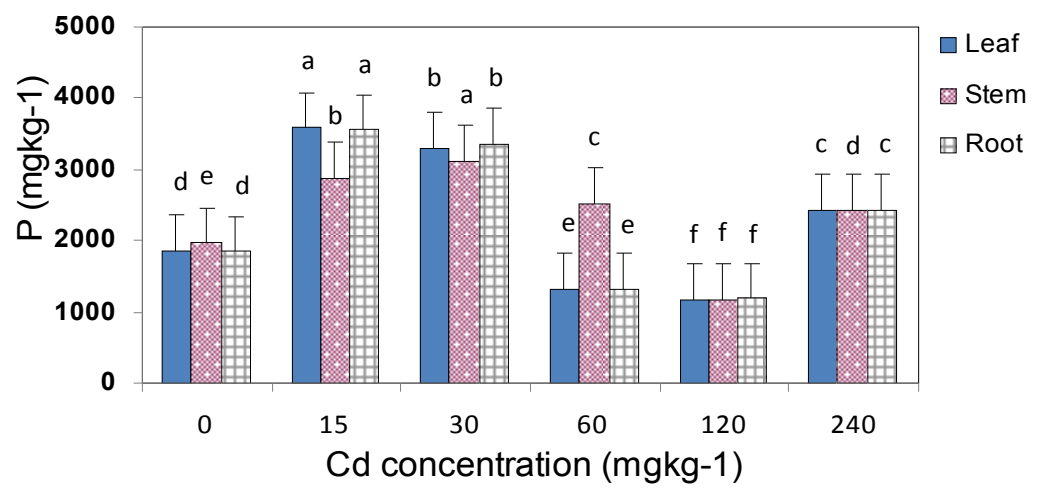

Figure 5. The concentration of $\mathrm{P}$ in leaves, stems and roots of Artemisia aucheriafter treating with various $\mathrm{Cd}$ concentration. Mean values within the same column, followed by different letters are significantly different using LSD protected test $(P<0.05)$. Data represent means \pm S.D.

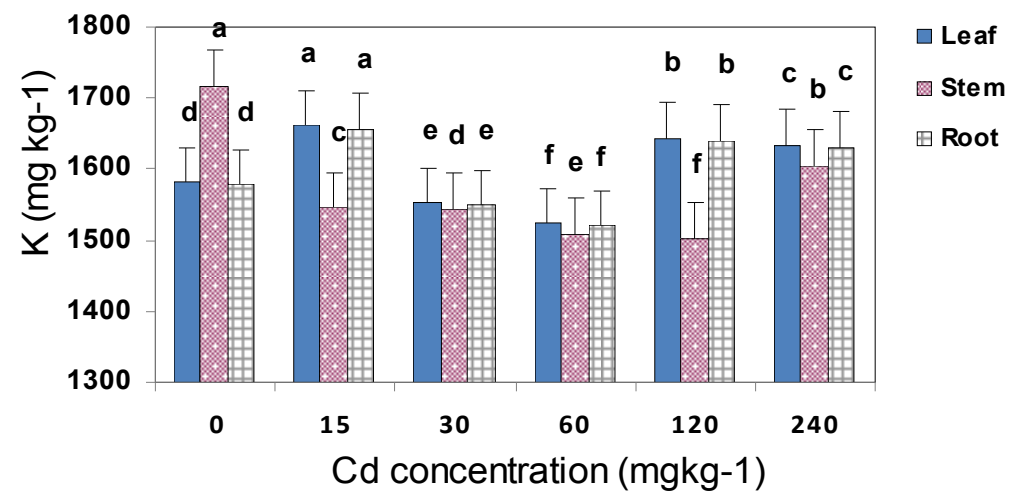

Figure 6. The concentration of $\mathrm{K}$ in leaves, stems and roots of Artemisia aucheriafter treating with various $\mathrm{Cd}$ concentration. Mean values within the same column, followed by different letters are significantly different using LSD protected test $(P<0.05)$. Data represent means \pm S.D.

\subsection{Shoot Mg and Micronutrients}

The $\mathrm{Mg}$ concentrations in the shoots increased as Cd levels increased from 0 to $60 \mathrm{mg} \mathrm{kg}^{-1}$, it then markedly decreased at the range of $120-240 \mathrm{mg} \mathrm{Cd} \mathrm{kg}^{-1}(p<0.05)$. Mn accumulation in shoots decreased with increasing soil Cd concentrations. The accumulation of Mn was the highest in the shoots of control plants $(p<0.05)$ (Table 1). Copper content of shoots decreased with increasing $\mathrm{Cd}$ concentration. The highest $\mathrm{Cu}$ concentrations were 
related to the control plants $(p<0.05)$ (Table 1). The Fe concentration in A. aucheri shoots decreased significantly as $\mathrm{Cd}$ concentration increased from 15 to $240 \mathrm{mg} \mathrm{kg}^{-1}$. The $\mathrm{Zn}$ concentrations in the control plants were higher than all the other treatments $(p<0.05)$. Zinc concentrations in the shoots were significantly reduced when $\mathrm{Cd}$ concentration increased from 15 to $240 \mathrm{mg} \mathrm{kg}^{-1}$. The concentration of $\mathrm{Zn}$ in the shoots of $A$. aucheri was maximal at control $(p<0.05)$ (Table 1).

Table 1. Mean comparison of shoot content of $\mathrm{Mg}, \mathrm{Mn}, \mathrm{Cu}, \mathrm{Fe}$ and $\mathrm{Zn}$ affected by different $\mathrm{Cd}$ concentrations

\begin{tabular}{cccccc}
\hline $\begin{array}{c}\text { Cd concentration } \\
\left(\mathrm{mg} \mathrm{kg}^{-1}\right)\end{array}$ & $\begin{array}{c}\mathrm{Mg} \\
\left(\mathrm{mg} \mathrm{kg}^{-1}\right)\end{array}$ & $\begin{array}{c}\mathrm{Mn} \\
\left(\mathrm{mg} \mathrm{kg}^{-1}\right)\end{array}$ & $\begin{array}{c}\mathrm{Cu} \\
\left(\mathrm{mg} \mathrm{kg}^{-1}\right)\end{array}$ & $\begin{array}{c}\mathrm{Fe} \\
\left(\mathrm{mg} \mathrm{kg}^{-1}\right)\end{array}$ & $\begin{array}{c}\mathrm{Zn} \\
\left(\mathrm{mg} \mathrm{kg}^{-1}\right)\end{array}$ \\
\hline 0 & $566.40^{\mathrm{e}}$ & $51.45^{\mathrm{a}}$ & $25.95^{\mathrm{a}}$ & $436.10^{\mathrm{a}}$ & $29.75^{\mathrm{a}}$ \\
15 & $733.20^{\mathrm{c}}$ & $43.90^{\mathrm{b}}$ & $19.80^{\mathrm{b}}$ & $324.70^{\mathrm{b}}$ & $28.75^{\mathrm{b}}$ \\
30 & $744.38^{\mathrm{b}}$ & $28.05^{\mathrm{c}}$ & $17.80^{\mathrm{b}}$ & $253.60^{\mathrm{c}}$ & $21.15^{\mathrm{c}}$ \\
60 & $748.30^{\mathrm{a}}$ & $22.50^{\mathrm{d}}$ & $13.11^{\mathrm{c}}$ & $207.80^{\mathrm{d}}$ & $18.70^{\mathrm{d}}$ \\
120 & $621.40^{\mathrm{d}}$ & $21.80^{\mathrm{d}}$ & $12.00^{\mathrm{cd}}$ & $185.80^{\mathrm{e}}$ & $16.68^{\mathrm{e}}$ \\
240 & $564.50^{\mathrm{e}}$ & $20.35^{\mathrm{e}}$ & $10.33^{\mathrm{d}}$ & $150.30^{\mathrm{f}}$ & $14.71^{\mathrm{f}}$ \\
\hline
\end{tabular}

Mean values within the same column, followed by different letters are significantly different using LSD protected test $(P<0.05)$. Data represent means \pm S.D.

\section{Discussion}

Chlorosis symptoms appeared on the leaves of A. aucheri grown in soil with $240 \mathrm{mg} \mathrm{kg}^{-1} \mathrm{Cd}$. Cadmium toxicity symptoms have been related to interactions between uptake and translocation of nutrients in plants. Leaf chlorosis resulted by Cd addition appeared to be associated with Fe (Foy et al., 1978) or Zn (Turner, 1973) in plants. Our results also indicate that shoot $\mathrm{Fe}$ and $\mathrm{Zn}$ content was reduced under $\mathrm{Cd}$ stress.

Figures 1 and 2 clearly demonstrate the adverse effects of different Cd-levels on plant biomass. The depression in plant growth as a result of excess Cd is similar to the result of Jiang et al. (2004), who reported that plant growth including root dry matter was negatively affected by Cd at $170 \mathrm{mg} \mathrm{Cd} \mathrm{kg}^{-1}$ soil dry weight. These results are also in agreement with the findings of Michalska and Asp (2001) and Jiang et al. (2003). Decreased plant growth by excess Cd can be attributed to the inhibition of cell growth (Prasad, 1995), mitosis, the decreased synthesis of cell-wall components, damage to the golgi apparatus, and alteration in the polysaccharide metabolism. However, browning is resulted by suberin storage (Punz \& Sieghardt, 1993).

Cadmium content of shoots increased with increasing soil $\mathrm{Cd}$. These results are in accordance with the observations of Jiang et al. (2004) and Zhao et al. (2003). Also, Vogel-Mikus et al. (2005) reported significant hyperaccumulation of $\mathrm{Cd}$ in shoots and roots with increasing $\mathrm{Cd}$ concentrations. Moreover, their findings showed that $\mathrm{Cd}$ concentrations in roots were significantly lower than shoots of Thlaspi praecox Wulfen (Brassicaceae). According to our results Cd concentrations in roots were higher than those in shoots (Figure 3). These results are contrary to the findings by Salt et al. (1997) and Jiang et al. (2004).

The highest $\mathrm{Cd}$ concentration in roots was found approximately at the $60 \mathrm{mg} \mathrm{Cd} \mathrm{kg}^{-1}$ dry weight soil. Thereafter, $\mathrm{Cd}$ concentration decreased in the roots (Figure 3). This result are in agreement with the results observed by De Oliveira et al. (1994) testing two soybeans varieties grown in a range of 0.2 to $1 \mathrm{mg} \mathrm{Cd} \mathrm{L}^{-1}$. Liu et al. (2006) also showed that the distributive levels of $\mathrm{Cd}$ in the roots of Zea mays reduced with increasing Cd concentration.

The results presented here indicate that the total $\mathrm{N}$ content of $A$. littoralis, growing at different $\mathrm{Cd}$ concentrations was higher than control (data not shown). This can be due to reduced plant growth. $\mathrm{N}$ concentration in stems and roots (but not in leaves) of sunflower seedlings (V4 stage) was significantly lower at the spilled-affected site (Madejon et al., 2003). Our results disagree with the work of Narwal et al. (1993) who indicated that excess Cd reduced maize $\mathrm{N}$ content.

Phosphorus deficiency is the second (after N) major nutrient limitation to plant growth. P concentration in plant tissues decreased with increasing Cd concentration, but it was increased by the $240 \mathrm{mg} \mathrm{kg}^{-1}$ treatment (Figure 5). Some researchers have indicated the adverse effect of Cd on P uptake by sunflower (Madejon et al., 2003) and maize (Narwal et al., 1993), while other researchers did not find changes in P uptake by maize (Nocito et al. 2002). A reduction in P concentration in all parts of cabbage was observed as excess lead was applied by Sinha 
et al. (2006). Michalska and Asp (2001) reported that Cd application did not have significant effects on the content of $\mathrm{P}$ in three lettuce cultivars.

The results in the present investigation demonstrated that $\mathrm{K}$ concentration decreased in different tissues of $A$. littoralis. However, it was increased in roots and leaves at the concentration of $240 \mathrm{mg} \mathrm{Cd} \mathrm{kg}$ and in stems at the concentration of $120 \mathrm{mg} \mathrm{Cd} \mathrm{kg}^{-1}$ (Figure 6). According to the literature, contradictory information can be found in the effects exerted by $\mathrm{Cd}$ on plant growth. Accordingly, Jiang et al. (2003) demonstrated that $\mathrm{K}$ content in the roots of indian mustard were not affected by Cd concentration ranging from 10 to $150 \mathrm{mg} \mathrm{Cd} \mathrm{kg}^{-1}$ soil dry weight. An enhancement was observed when $\mathrm{Cd}$ was added at $170 \mathrm{mg} \mathrm{kg}^{-1}$ soil dry weight. Cd content of indian mustard shoot increased at the $\mathrm{Cd}$ concentrations ranging from 10 to $110 \mathrm{mg} \mathrm{kg}^{-1}$, and then remained constant as $\mathrm{Cd}$ concentration increased from 110 to $190 \mathrm{mg} \mathrm{kg}^{-1}$. Also, an increase in $\mathrm{K}$ content was reported by Ciecko et al. (2004). However, Michalska and Asp (2001) and Narwal et al. (1993) observed that K content was decreased when $\mathrm{Cd}$ was added to the nutrient solution. This might have been because of the detrimental effects of $\mathrm{Cd}$ on the cellular plasma membrane of Spinacea oleracea L. root (Sadana \& Bijah 1987).

The Mg concentration in the A. aucherishoots increased as Cd concentration increased from 0 to $60 \mathrm{mg} \mathrm{kg}^{-1}$ soil dry weight, and then decreased (Table 1). Increased Mg content was reported by Obata and Umebayashi (1997), however Yang et al. (1996) observed a reduction in Mg content of plant shoot. According to Table 1, Mn accumulation in shoots decreased with increasing soil Cd concentrations. Obata and Umebayashi (1997), Madejon et al. (2003) and Lui et al. (2006) reported reduction in the shoot Mn content. Our finding is also in agreement with the reports by Hernández et al. (1998). Yang et al. (1996) also demonstrated a reduction in the root influx of Mn to plant shoot movement.

Shoot $\mathrm{Cu}$ content decreased when $\mathrm{Cd}$ was applied to the soil (Table 1). Our results are similar to the results of Breckle and Kahle (1992) and Liu et al. (2006). However, some contrary reports were made by Obata and Umebayashi (1997) and Madejon et al. (2003). The Fe concentration in A. aucherishoots decreased as Cd addition increased from 15 to $240 \mathrm{mg} \mathrm{kg}^{-1}$ (Table 1). Cadmium has been reported to reduce Fe uptake in different plants (Haghiri, 1973; Breckle \& Kahle 1992; Madejon et al., 2003). But, Jiang et al. (2004) and Liu et al. (2006) reported an increase in shoot Fe content as $\mathrm{Cd}$ concentrations increased.

The Zinc concentration in the shoots was reduced when Cd concentration increased from 15 to $240 \mathrm{mg} \mathrm{kg}^{-1}$ (Table 1). In the research work by Michalska and Asp (2001) Zn showed no clear response to Cd treatment. Reduction of plant $\mathrm{Zn}$ content under Cd stress has been indicated by some workers (e.g. Marschner 1995; Turner, 1973; Thomas \& Harrison, 1989). However, the findings of Madejon et al. (2003) indicated that shoot $\mathrm{Zn}$ content increased. However, Jiang et al. (2004) found that $\mathrm{Zn}$ concentrations in shoots of indian mustard was initially increased as $\mathrm{Cd}$ concentration increased and then it markedly decreased and remained constant.

\section{Conclusion}

In conclusion, the pot-culture experiment conducted with excess $\mathrm{Cd}$ concentrations demonstrated that $\mathrm{Cd}$ stress significantly reduced plant biomass production. It also altered $\mathrm{Cd}$ and nutrients uptake and translocation in $A$. littoralis. In this study, low and high Cd concentrations in the roots $\left(12.42 \mathrm{mg} \mathrm{kg}^{-1}\right)$ and shoots $\left(77.05 \mathrm{mg} \mathrm{kg}^{-1}\right)$ was observed indicating that $A$. aucherican be appropriately used for phytoextraction use. Interestingly, Cd excess amounts increased the uptake of plant macronutrient and decreased the uptake of plant micronutrients. In the next research work, we can look for methods, resulting in the enhancement of A. aucheriability to absorb Cd.

\section{References}

Breckle, S. W., \& Kahle, H. (1992). Effect of toxic heavy metals $(\mathrm{Cd}, \mathrm{Pb})$ on growth and mineral nutrition of beech (Fagus sylvatica L.). Veg., 101, 43-53. http://dx.doi.org/10.1007/BF00031914

Ciecko, Z., Kalembasa, S., Wyszkowski, M., \& Rolka, E. (2004). Effect of soil contamination by cadmium on potassium uptake by plants. Pollish J. of Environ Studies, 13, 333-337.

De Oliveira, J. A., Oliva, M. A., Cambraia, J., \& Venegas, V. H. A. (1994). Absorption, accumulation and distribution of cadmium by two soybean cultivars. R. Bras Fisiol Veg., 6, 91-95.

Foy, C. D., Chaney, R. L., \& White, M. C. (1978). The physiology of metal toxicity in plants. Ann Rev Plant Physiol, 29, 511-566. http://dx.doi.org/10.1146/annurev.pp.29.060178.002455

Glass, D. J. (2000). Economical potential of phytoremediation. In I. Raskin, \& B. D. Ensley (Eds.), Phytoremediation Toxic Metals: Using Plants Clean Up Environment (pp. 15-31). New York: John Wiley and Sons. 
Haghiri, F. (1973). Cadmium uptake by plants. J. Environ Qual., 2, 93-96. http://dx.doi.org/10.2134/jeq1973.00472425000200010012x

Hernández, L. E., Lozano-Rodríguez, E., Gárate, A., \& Carpena-Ruiz, R. (1998). Influence of cadmium on the uptake, tissue accumulation and sub cellular distribution of manganese in pea seedlings. Plant Sci., 132, 139-151. http://dx.doi.org/10.1016/S0168-9452(98)00011-9

Jiang, X. J., Luo, Y. M., Liu, Q., Liu, S. L., \& Zhao, Q. G. (2004). Effects of cadmium on nutrient uptake and translocation by Indian mustard. Environ Geochem Health, 26, 319-324. http://dx.doi.org/10.1023/B:EGAH.0000039596.15586.b3

Jiang, X. J., Luo, Y. M., Zhao, Q. G., Baker, A. J. M., Christie, P., \& Wong, M. H. (2003). Soil Cd availability to Indian mustard and environmental risk following EDTA addition to Cd-contaminated soil. Chemosphere, 50, 813-818. http://dx.doi.org/10.1016/S0045-6535(02)00224-2

Liao, B., Liu, H., Zeng, Q., Yu, P., Probst, A., \& Probst, J. (2005). Complex toxic effects of $\mathrm{Cd}^{2+}, \mathrm{Zn}^{2+}$, and acid rain on growth of kidney bean (Phaseolus vulgaris L). Environ Int., 31, 891-895. http://dx.doi.org/10.1016/j.envint.2005.05.029

Liu, D. H., Wang, M., Zou, J. H., \& Jiang, W. S. (2006). Uptake and accumulation of cadmium and some nutrient ions by roots and shoots of maize (Zea maize L.). Pak J. Bot., 38, 701-709.

Madejon, P., Murillo, J. M., Maranon, T., Cabreraa, F., \& Soriano, M. A. (2003). Trace element and nutrient accumulation in sunflower plants two years after the Aznalcollar mine spill. The Sci. Total Environ., 307, 239-257. http://dx.doi.org/10.1016/S0048-9697(02)00609-5

Marschner, H. (1995). Mineral Nutrition of Higher Plants. London: Academic Press Limited.

McBride, M. B. (1994). Environmental Chemistry of Soils. New York: Oxford University Press.

Michalska, M., \& Asp, H. (2001). Influence of lead and cadmium on growth, heavy metal uptake and nutrient concentration on three lettuce cultivars grown in hydroponic culture. Commun Soil Plant Anal., 32, 571583. http://dx.doi.org/10.1081/CSS-100103029

Narwal, R., Mahendra-Singh, P., \& Singh, M. (1993). Effect of cadmium and zinc application on quality of maize. Ind J. Plant Physiol., 36, 170-173.

Nocito, F. F., Pirovano, L., Cocucci, M., \& Sacchi, G. A. (2002). Cadmium induced sulphate uptake in maize roots. Plant Physiol., 129, 1872-1879. http://dx.doi.org/10.1104/pp.002659

Nouairi, I., BenAmmar, W., BenYoussef, N., Daoud, D. B., Ghorbal, M. H., \& Zarrouk, M. (2006). Comparative study of cadmium effects on membrane lipid composition of Brassica juncea and Brassica napus leaves. Plant Sci., 170, 511-519. http://dx.doi.org/10.1016/j.plantsci.2005.10.003

Obata, H., \& Umebayashi, M. (1997). Effects of Cadmium on Mineral Nutrient Concentrations in Plants Differing in Tolerance for Cadmium. J. Plant Nutr., 20, 97-105. http://dx.doi.org/10.1080/01904169709365236

Page, A. L., Miller, R. H., \& Keeney, D. R. (1982). Methods of Soil Analysisd Chemical and Microbiological Properties. Madison, Wisconsin.

Pál, M., Horváth, E., Janda, T., Páldi, E., \& Szalai, G. (2006). Physiological changes and defense mechanisms induced by cadmium stress in maize. J. Plant Nutr Soil Sci., 169, 239-246. http://dx.doi.org/10.1002/jpln.200520573

Prasad, M. N. V. (1995). Cadmium toxicity and tolerance in vascular plants. Environ Exp Bot., 35, 525-545. http://dx.doi.org/10.1016/0098-8472(95)00024-0

Punz, W. F., \& Sieghardt, H. (1993). The response of roots of herbaceous plant species to heavy metals. Environ Exp Bot., 33, 85-98. http://dx.doi.org/10.1016/0098-8472(93)90058-N

Sadana, U. S., \& Bijah, S. (1987). Effect of Zinc application on yield and cadmium content of spinach (Spinacea oleracea L.) grown in a cadmium polluted soil. Ann Bot., 3, 59-60.

Salt, D. E., Pickering, I. J., Prince, R. C., Gleba, D., Dushenkov, S., Smith, R. D., \& Raskin, I. (1997). Metal accumulation by aquacultured seedlings of Indian mustard. Environ Sci. Technol., 31, 1635-1644. http://dx.doi.org/10.1021/es960802n 
Shevyakova, N. I., Netronina, I. A., Aronova, E. E., \& Kuznetsov, V. V. (2003). Compartmentation of cadmium and iron in Mesembryanthemum crystallinum plants during the adaptation to cadmium stress. Russ J. Plant Physiol., 50, 678-685. http://dx.doi.org/10.1023/A:1025652510658

Singh, S., Eapen, S., \& D'Souza, S. F. (2006). Cadmium accumulation and its influence on lipid per oxidation and anti oxidative system in an aquatic plant, Bacopa monnieri L. Chemosphere, 62, 233-246. http://dx.doi.org/10.1016/j.chemosphere.2005.05.017

Sinha, P., Dube, B. K., Sriastava, P., \& Chatterjee, C. (2006). Alteration in uptake and translocation of essential nutrients in cabbage by excess lead. Chemosphere, 65, 651-656. http://dx.doi.org/10.1016/j.chemosphere.2006.01.068

Siroka, B., Huttova, J., Tamás, L., Simonoviva, M., \& Mistrik, I. (2004). Effect of cadmium on hydrolytic enzymes in maize root and coleoptile. Biologia, 59, 513-517.

Thomas, G. M., \& Harrison, H. C. (1989). Inheritance of Cadmium Concentration in Lettuce. J. Am Soc Hort Sci., 114, 121-125.

Turner, M. A. (1973). Effect of cadmium treatment on cadmium and zinc uptake by selected vegetable species. J. Environ Qual., 2, 118-119. http://dx.doi.org/10.2134/jeq1973.00472425000200010020x

Vogel-Mikus, K., Drobne, D., \& Regvar, M. (2005). Zn, Cd and Pb accumulation and arbuscular mycorrhizal colonisation of pennycress Thlaspi praecox Wulf. (Brassicaceae) from the vicinity of a lead mine and smelter in Slovenia. Environ Pollut., 133, 233-242. http://dx.doi.org/10.1016/j.envpol.2004.06.021

Yang, X., Baligar, V. C., Martens, D. C., \& Clark, R. B. (1996). Cadmium effects on influx and transport of mineral nutrients in plant species. J. Plant Nutr., 19, 643-656. http://dx.doi.org/10.1080/01904169609365148

Zhao, F. J., Lombi, E., \& McGrath, S. P. (2003). Assessing the potential for zinc and cadmium phytoremediation with the hyperaccumulator Thlaspi caerulescens. Plant Soil, 249, 37-43. http://dx.doi.org/10.1023/A:1022530217289 